\title{
PERSPECTIVES TO IMPROVE THE FLUIDITY OF TRAFFIC AND ACCIDENTS REDUCTION IN THE GRADUAL INSERTION OF AUTONOMOUS VEHICLES IN THE CITY OF SÃO PAULO
}

\author{
Luiz Vicente Figueira de Mello Filho ${ }^{1}$, Yuzo Iano ${ }^{2}$, \\ Murilo Cesar Perin Briganti ${ }^{3}$ e Raquel Cardamone ${ }^{3}$ \\ ${ }^{1}$ Universidade Presbiteriana Mackenzie \\ ${ }^{2}$ Universidade Estadual de Campinas \\ ${ }^{3}$ Bright Consulting \\ E-mails: luiz.mello@mackenzie.br; yuzo@ decom.fee.unicamp.br; \\ murilo.briganti@brightisd.com; e \\ raquel@brightisd.com
}

\begin{abstract}
This study aims to present a projection of the insertion of autonomous vehicles and the impacts generated in the flow of traffic, in the behavior of society and in the positive perspectives in the reduction of accidents. Based on the current surveys of accidents involving autonomous vehicles in the United States by the Uber passenger Transport Company and the Tesla individual transportation company, there is a projection of an increase in the number of autonomous vehicles in circulation in the city of São Paulo to next 20 years. The effects of new legislation and changes in the habits of society tend to reduce the number of accidents in large urban centers, mainly due to the low orientation / education of the population, due to a national culture that prevails in urban areas the domain of motor vehicles in relation to pedestrians and cyclists.
\end{abstract}

\section{INTRODUCTION}

The accelerated growth and lack of efficient planning of the city of São Paulo can be considered an example of when urban mobility becomes a serious problem. According to Rolnik and Klintowitz (2011) "Every month, Paulistano spends two days and six hours in the car or public transportation to get around. Paulistas lose, on average, 27 days a year trapped in congestion".

The lack of planning for traffic education since the school period and habits such as not crossing the road, passing the vehicle at the red light, not respecting speed limits, making abrupt changes in lanes, driving drunk and using smartphones In traffic, among others, are some everyday examples that aggravate the result in the number of accidents.

The internet of things and the insertion of autonomous vehicles tend to reduce the number of accidents in countries where compliance with traffic laws that is not done in integrity and are part of the large percentage of accidents on public roads. 
The largest collective transport network is still by bus, but investments in quality and training of professionals in the selection of drivers of human lives is still a great challenge. Semiautonomous technology can be the success for accidents to be avoided.

The motorcycle, the main vehicle for traffic accidents, is the most fluid vehicle in traffic, but the most insecure one in driving, especially due to a lack of compliance with traffic laws.

The following is an analysis to improve traffic flow and reduce accidents with the use and advancement of technologies that will embark on urban mobility in the coming years.

\section{ANALYSIS OF MODALITIES AND TRANSIT IN THE CITY OF SÃO PAULO}

São Paulo is located in southeastern Brazil at an average altitude of 799 meters of sea level. According to the Brazilian census (IBGE, 2010) of the Geographical and Statistical Institute, $11,245,983$ people reside only in the city, and people between 16 and 64 years old are 7,996,444 and over 55 are 914,570 .

In 2012 Law No. 12,587 / 12, known as the Urban Mobility or Urban Mobility Policy, entered into force. Among the most relevant points are: the prioritization of non-motorized modes and collective public transport, the establishment of pollutant emission standards, democratic management and social control of planning and evaluation of mobility policy, and a new management On transport tariffs and the integration of development policies.

The current law succinctly describes that the construction of a public road that provides exclusivity for automobiles violates the principle established by the law on equity in the use of public traffic, the prioritization of non-motorized and collective transportation.

\footnotetext{
$\S 1^{\circ}$ Municipalities above 20,000 (twenty thousand) inhabitants and in all other obligations, according to the law, to the preparation of the master plan, the Urban Mobility Plan must be prepared, integrated and compatible with the respective master plans or inserted in them (Lei $\left.\mathrm{n}^{\circ} 12.587,2012\right)$.
}

In practice, to date, there have been no significant efforts to effectively comply with this law, especially with regard to investment in public transport, whether by bus or train. The predominance of alternatives for individual transportation is a reality, but the purchasing power of the population, as well as the crisis in the country, which extends for more than 2 years ago, prevents natural migration to individual transportation, whether private or contracted.

Displacement is part of the seven forms of waste presented by Taichi Ohno (1997). There are modalities that fit in being productive in the displacement by the fact of not being the conductor. Others risk doing more than one activity at a time, which implies the greatest risk of accidents.

The following describes the transport modalities available in the city and the restrictions of each one of them.

\subsection{Pedestrians and cyclists}

We are all pedestrians and for this simple reason the first public access is the sidewalk. The first law of São Paulo city referring to the subject was the one of 1969 of $\mathrm{n}^{\circ} 7.359$. But only recently 
it has been emphasized in the matter with the Law of conservation of the sidewalks no. 15,442 of 2011 and changed to Law 15,733 of 2013, but visually there is no effective compliance.

The bus stops, which even with the improvement partly in the city with a glazed design, prioritizes the advertising and not the visual communication of the bus routes and, consequently, occupies the space for the locomotion of the pedestrian on the roads. At night time there is not adequate lighting at most points. Unlike the totem of commercial advertisement in the same place, well visible to drivers of motor vehicles.

Ideal sidewalk designs should be provided with a pedestrian walking area, known as a walking path, a bike path where possible and lastly the range of services, which comprises, in order: afforestation and the installation of urban furniture, which It includes garbage collection points, the bus stop, public telephones and newsstands (DUARTE et al, 2012).

Another point on public roads is the use of the tactile floor in the pedestrian circulation area for the visually impaired, slope changes on the ramps and access of the lowered guides at the crossing lanes. Decree No. 45,904 of 2005 addresses these issues, but we have not yet routinely witnessed these conditions on the streets.

Modification of the modalities of this modality is effectively positive since $32 \%$, which represents 14 million trips a year, are done in a non-motorized way (PUBLICAÇÃO METRÔ, 2013).

The range of services is the ideal spot for planting grasses in the intervals of the trees, as long as it does not hamper accessibility at the crossings. Environmentally, it increases the uptake of $\mathrm{CO}_{2}$, reduces the point temperature of the roads and visually improves the range of the route.

Of these changes, there is the regulation of parklet, which is an area of coexistence in the urban center that replaces some vacancies for automobiles and enables the interaction of the pedestrian public with the environment. Used in regions of great densification and economic centers.

By the year 2015, according to CET (2015), the cycle network of the São Paulo city had 360.1 $\mathrm{km}$ of permanent infrastructure, being $328.2 \mathrm{~km}$ of bike path / cycle path and $31.9 \mathrm{~km}$ of cycle paths. However, if there is no structured programming for cyclist-only routes, there is a very high risk of deterioration and increased accidents.

The use of cycle paths and / or cycle paths are directly linked to the topographic conditions of the city and the ambient temperatures throughout the year, which depending on the period, many kilometers tend to be underutilized. The sidewalks without proper maintenance end up being an invitation not to walk, either.

\subsection{Subway and train}

The subway, inaugurated in September 1974, completed 43 years of existence. It is only with a length of 81.1 kilometers of railway lines distributed in five lines, linked by 71 stations (METRO, 2017). 
To complement this deficiency, there is the transport by train, that unlike the subway, has the metropolitan extension, reaching the more distant regions of the city. Contemplating the trains, the metropolitan region has more than 260 kilometers of extension distributed in nine lines with 92 stations. Overcrowding and occasional breaks or work stoppages aggravate the disability and discourage new audiences, regardless of purchasing power. In the last five years of operation, line 10 (Turquesa) lost 8 million passengers (MACÁRIO, 2017), who possibly opted for another modal or moved to other regions of the city or even decreased the circulation of people due to the economic crisis.

The monorail, whose construction time should be less than that of the subway, but has a lower capacity than the number of passengers per hour and per direction. It is a clean and sustainable alternative, as well as Light Rail Vehicles (VLTs). But the attractiveness of rail transport becomes predictable, safe and comfortable due to the number of users, in order to reduce the use of individual transport, is far from occurring.

The monthly salary of the driver, considering an average of the function, is $\mathrm{R} \$ 3,889.00$, which is equivalent to US\$ $1,196.00$ (dollar quoted at $\mathrm{R} \$ 3.26$ ) according to the working time and the positioning of the function, between others.

\subsection{Bus and BRTs (Bus Rapid Transit)}

The current bus fleet is 14,671 vehicles and they use 1,281 lines in 1,782 kilometers of extension, considering the overlap of the lines. The fleet has an average age of 3 to 5 years between the contracts of concession and concession for the public service (PUBLICAÇÃO SPTRANS, 2014). The current BRT is called Expresso Tiradentes, former name "Fura Fila", located on the pillars of the Avenues of Juntas Provisórias and Estado and has an extension of 12 kilometers.

In the collective modals, 16.1 million trips were made in 2012, representing $54.3 \%$ of those made by bus, charter, trains and subway (PUBLICAÇÃO METRÔ, 2013).

The passenger capacity per hour per direction for the transport on tires depends on the size of the bus, being a more complex task to balance the needs of the passengers in different locations. The increase in the number of BRTs, which uses exclusive corridors and collection of the fare at stopping points, is an outlet to equalize the capacity deficiencies of trains and subways, and may in the future be an autonomous vehicle.

Due mainly to the requirements of BRT employment, an option with faster and less costly deployment for public power is in the creation of exclusive bus lanes. With this aim of improving mobility, one more than 300 kilometers of these exclusive tracks were created in 2013.

The monthly salary of the bus driver, considering an average of the function, is $\mathrm{R} \$ 2,375.00$, which is equivalent to $\mathrm{U} \$ 728.52$, and the collector is $\mathrm{R} \$ 1,218.00$, which is equivalent to $\mathrm{U} \$$ 373.62 (quoted dollar To R \$ 3.26) depending on the working time and the qualifications of drivers. Adding the two categories by bus, we have a value of $\mathrm{R} \$ 3,593.00$, which is equivalent to U\$ 1,102.14 (LOVE MONDAYS, 2017). 
The driver's truck salary is $\mathrm{R} \$ 1,852.00$. The salary levels of drivers and other positions directly related to the profession and regulated in the State of São Paulo, Rio de Janeiro and Santa Catarina is $\mathrm{R} \$ 1,637.00$ (PISO SALARIAL, 2017). The salary floor for bus drivers is $\mathrm{R} \$$ 1,500.00 (LOVE MONDAYS, 2017).

The passenger has the possibility of being productive and connected with WiFi network, in some cases in the vehicle itself. However, factors such as transport capacity and deficiency in the control of the safety of the passenger in transit, does not remain in a suitable environment to take better advantage of the time in the displacements.

\subsection{Motorcycles}

Motorcycle manufacturing has tax incentives, one of which is the exclusion of IPI (Industrialized Product Tax), as well as the import format of industrialized components; so much so that, since the creation of the Manaus Free Zone in the state of Amazonas, the companies are located in the same industrial park.

From the 1990s there was an incentive for the purchase and use of this modal that reached a Brazilian fleet of 1.5 million, passing to 17 million motorcycles in 2012 (VASCONSELLOS, 2013).

In the city of São Paulo, the number of motorcycles increased from 50 thousand in 1990 to 750 thousand in 2011 (DENATRAN, 2012). Motorcycles up to $150 \mathrm{cc}$ (cubic centimeters) accounted for $88.8 \%$ of production in 2003 and 2009 (ABRACICLO, 2012).

The production of motorcycles was directed, in large part, to the low-income population that acquired the good many times through financing. Expenses for the low maintenance value and fuel consumption associated with the ease of driving on urban roads quickly popularized this means of transport in large centers. The mode of motocargo, known as motoboys, in the great centers was pulverized.

Publicity campaigns in the 2000s were also made on the modalities on rails that encouraged choosing in the purchase of an individual transport due to the equalization of values with the collective transportation. There were also campaigns in magazines. This transport brings many benefits, but leaves something to be desired in terms of safety and comfort on the roads.

According to SOUZA (2014), the monthly cost to maintain a motorcycle 150 cc (cubic centimeters) is $R \$ 210.00$ monthly, excluding the acquisition of the good. This configuration is calculated for a zero kilometer vehicle, which runs monthly $40 \mathrm{~km}$ per day, regularly makes all technical revisions according to the owner's manual, has theft insurance and makes annual licensing.

Considering that the bus ticket in 2014 was R $\$ 3.00$ and using the bus/train/ subway 21 working days per month in the year 2014 (BUSINESS DAYS, 2014). We have a monthly amount of R\$ 126.00. If the trip is by intermunicipal bus, it depends on route variations in the values from $R \$$ 2.25 to R \$5.50 for the Grande ABC from 2013 to 2014 (PUBLICAÇÃO G1, 2013). In this case, considering the average of $\mathrm{R} \$ 3.88$ per ticket in the Grande $\mathrm{ABC}$, the monthly cost would be $\mathrm{R} \$ 163.00$. 
In short, the attractiveness of the motorcycle is very large due to the use of public transport. There was an increase of $\mathrm{R} \$ 84.00$ per month in the São Paulo city using bus/ train/ subway and $\mathrm{R} \$ 47.00$ per month for intercity buses in Grande ABC.

\subsection{Automobiles}

In $2012,45.7 \%$ of the population, which represented 13.6 million trips, was made by individual mode, automobiles, taxis and motorcycles (PUBLICAÇÃO METRÔ, 2013).

In the period that Juscelino Kubitschek de Oliveira assumed the Presidency of the Republic. One more precisely in 1956, there was the greatest incentive in the automobile industry made by a working group and later made official as GEIA (Automotive Industry Executive Group). This group favored the multinational companies already installed as well as the entry of others in Brazil in the metropolitan region of São Paulo.

The road expansion model benefited buses and cars. For example, we can mention exclusive roads to automobiles, such as the High Presidente Costa e Silva in 1971, known as the minhocão and the Ayrton Senna Road Complex in 1995. In addition, there was a widening of streets and avenues favoring more transport on wheels than the non-motorized.

The second incentive to the production of cars occurred in the mid-1990s with the popular car modality with 1 liter engines, encouraging the purchase of this configuration due to the tax reduction, going back to the manufacture of the Fusca model, except in the specification of the engine.

In 1997, the municipal rotation of environmental character and unpopular measure, became a strategy in the reduction of cars in the peak times. As critical as it is to the effectiveness of this restriction nowadays, there is no policy regarding the exclusion of this consolidated measure in the city.

In the last 12 years there has been an individual vehicle cheaper and an increase in public transport buses according to the inflation of these years, considerably stimulating the migration from public to private transport (CARVALHO, 2014).

In 2009, there was the implementation of the environmental vehicle inspection in the city of São Paulo for private, collective and registered motor vehicles registered in the city. It was also an unpopular measure, but of positive effects on the environment and the health of the population. The objective was to keep the vehicles within the standards set by the automakers, encouraging preventive maintenance. Due to the unsustainability between the granting authority and the concessionaire providing service, was suspended in 2014 for an indefinite period.

In 2012, Law 12,715 was created regarding the Incentive Program for Technological Innovation and Automotive Vehicle Productive Chain (Inovar-Auto), which sought systemic gains in efficiency and increased productivity in the automotive chain, which introduced the benefit to the manufacturers installed In Brazil with a reduction in the percentage of IPI (Law No. 12,715, 2012). Inovar-Auto 2 also seeks to include safety equipment for benefits gains. 
Due to a need to use a taxi by the founders Travis Kalanick and Garrett Camp in the year of 2008, Uber company appeared, that has transformed the modality of the automobile by the world. They are currently in 604 cities and have more than 1 billion connections (PUBLICAÇÃO UBER, 2017).

The displacement of people by private vehicle, when you have only the driver per vehicle, does not add value. In the case of vehicles with drivers, such as taxis, UBERs and other companies in this field, they can improve traffic safety and prevent professionals from doing more than one activity at the same time, increasing productivity during the period of travel with this modality.

Tests with Uber in Arizona reported an accident after the tests reached 3.2 million kilometers (BERGEN, 2017). The introduction of Autopilot in Tesla vehicles, according to the manufacturer, reduced the number of accidents involving Tesla models with this technology by 40\% (BOUDETTE, 2017).

In short, the automobile is the most representative mode and choice when the economy of the country goes well, mainly to the difficulties encountered in other modes. However, when the economy goes badly and unemployment rates increase. The admission to register as a driver of the UBER increases and the competition with the taxis, they follow the same proportion, generating discomfort and conflicts with a stagnant class for the purpose of improvement.

\section{THE TESTS AND MARKETING OF AUTONOMOUS VEHICLES}

Disruptive innovation in the automotive industry is currently occurring on several fronts.

New mobility services are changing the transportation sector, either by providing entirely new mobility solutions or by reshaping traditional transportation means with technology (ridesharing with carpooling, microtransit with bus shuttles). As a result, there is more diversity in terms of transportation solutions and a greater offer of individual mobility, as opposed to collective mobility (public transit).

New mobility services (NMS) have been characterized as more reliable, predictable, efficient, convenient, accessible, and seamlessly connected compared to established means of transportation, as well as offering easier options for payment. NMS, such as ridehailing and carsharing, also contribute to reduced demand for parking, pollution, and congestion, as well as provide energy savings and transportation costs savings for users.

Ridehailing started in the late 2000s in the United States and is now available in most of the world. The biggest Connected Transportation company is Uber (present on all continents), followed by regional players such as Lyft (United States) and Didi (China). Conceptually, ridehailing distinct from ridesharing.

Ride-hailing encompasses a range of companies and services, including traditional taxis and car services. It services rely on smartphone apps to connect paying passengers with drivers who provide rides (for a fee) in their private vehicles. 
Ride-sharing is a synonym for sharing a ride with another passenger. It is a type of carpooling that uses private vehicles, arranging shared rides on short notice between travelers with a common origin and/or destination.

Overall, the growth of new mobility services has been associated with a decrease in the use of private cars and an increase in public transit use; however, some people also prefer new mobility services over public transit in certain circumstances. For example, research indicates that people prefer carsharing or ridehailing to public transit, if the transit trip takes longer or requires several changes. According to Datafolha, the survey also showed that a quarter of the population in the city of São Paulo has already picked up an Uber, and 93\% of them have evaluated the service as good or excellent. In total, new mobility services substitute for more private vehicle trips than for public transit trips (GLOBO/DATAFOLHA, 2016).

Ridehailing has a particularly important impact on taxis and rental cars, in addition to the implications for the use of private vehicles and public transit mentioned above. In terms of gross revenue, Uber already surpasses conventional taxis in several cities. After ridehailing gained in popularity for personal use, corporate users started shifting towards these services as well. In reaction to that, Uber and Lyft now have programs for corporate travel.

One of the few available studies about the growth of Uber in the United States shows the exponential growth of the number of active driver-partners between mid-2012 (launch of UberX) and late-2014, when the service had more than 160,000 drivers. In this two-year period, the number of new driver-partners more than doubled every six months. According to information released by Uber in April 2016, more than 450,000 driver-partners worked with the company. In the city of São Paulo between 2015 and 2016 was an increase of more than $50 \%$ in the emission of CNHs (Driver's license) with the note "has paid activity", requirements for working in Uber and similar. According to data from the Detran, the number rose from 100,000 in the capital in the first five months of 2015 to almost 160 thousand in the same period of 2016 (Detran, 2016).

The growth of the ridehailing business is boosted by a high consumer preference, the ability to fill transportation needs not well met by other modes, and a yet ill-defined regulatory framework. Given their high growth potential, investors have taken an interest in ridehailing. Companies like Uber and Lyft have so far received about $\$ 9$ billion investments in 2016, almost twice than any other startup segment in all 2015.

Other than Uber, companies like Google and Tesla, also stand to disrupt the automotive industry with their autonomous vehicle projects, expanded network of electric vehicle battery charging stations, and ride-sharing services respectively.

Fully autonomous vehicles (AVs) are unlikely to be commercially available before 2020. In Brazil, due to high taxes and high cost of vehicles this trend tend to begin at least ten years later. Meanwhile, advanced driver assistance systems (ADAS) will play a crucial role in preparing regulators, consumers, and corporations for the medium-term reality of cars taking over control from drivers.

The technological challenges are not insignificant, and will likely drive the delay between conditionally autonomous cars which allow the driver to cede control in certain situations as Level 3 according to the National Highway Traffic Safety Administration (NHTSA), and fully 
autonomous cars, which require no driver intervention for the entire trip (Level 4 NHTSA). Tech players and startups will likely play an important role in achieving this level of technical complexity. Regulation and consumer acceptance represent additional hurdles for autonomous vehicles. However, once these challenges are addressed, autonomous vehicles present a tremendous value offering for consumers (e.g., ability to work while commuting, convenience of using social media, or resting while traveling) (PUBLICAÇÃO FUTURISM, 2017).

Stricter emission regulations, lower battery costs, widely available charging stations, and increasing consumer acceptance will create new and strong momentum for penetration of electrified vehicles (hybrid, plug-in, battery electric, and fuel cell) in the coming years. The speed of adoption will be determined by the interaction of consumer pull (partially driven by total cost of ownership) and regulatory push, which will vary strongly at the regional and local level. Adoption rates will be highest in developed, dense cities with strict emission regulations and consumer incentives (tax breaks, special parking and driving privileges, discounted electricity pricing, etc.). Sales penetration will be slower in small towns, rural areas or cities with lower levels of charging infrastructure and low financial benefits/incentives for the consumer (ICCT).

Overall, the evolution of technology and digitization of products and services in our society have given companies the opportunity to create digital business models that allow them to increase inventories as well as the demand for their products with little or no additional cost per unit. Companies like Uber and AirBNB use online interfaces to provide consumers with services provided by their peers, which has allowed the viral loop effect to create a number of million-dollar companies in a matter of weeks.

Furthermore, the process of disruptive innovation is allowing these same companies to revolutionize markets by developing technology to a point where they can replace existing products and services with better ones, all for a lower cost.

These trends stand to not only increase efficiency for commuters, but also improve highway safety, and reduce the amount of fossil fuel used by the average motorist. These disruptions may require current automotive industry leaders to re-evaluate and improve their products, or lose out to these technology-based companies.

California is the current capital for autonomous vehicle technology, and has the potential to become an automotive-heavy state in the future if they continue this development path. São Paulo has a huge opportunity by having important centers of research and development and Universities, but does not have enough incentives.

\section{TRAFFIC ACCIDENTS IN THE SÃO PAULO CITY}

In Brazil, traffic accidents still provide a large amount of lives lost annually. Currently the country occupies the fifth highest number in the number of causes of traffic deaths.

Second data from the Ministério da Saúde in 2012 were more than 44,800 dead in accidents and about 179,000 injured (POR VIAS SEGURAS, 2014). These disproportionate numbers are impressive because they kill more than many tropical diseases that hit the Brazilian population. 
The importance of road safety in Brazil still has a small space in the political-social scenario. Although recent actions approved in the Congresso Nacional that alter several articles of the Brazilian traffic code, increasing the punishment of traffic offenders law 12.971 / 14. Whose aim is to reduce the main causes of death, such as: alcoholism, cracks dispute and dangerous overtaking (SOUZA; TEIXEIRA; TUMA JUNIOR, 2014).

In 2014, 1,249 people died and 441 were injured in traffic accidents in the city of São Paulo, according to CET, based on the records of the Instituto Médico Legal - IML. The number of deaths increased by $8.4 \%$ in 2014 compared to 2013, the first increase since 2011 . Among the main fatal traffic fatalities in the city, pedestrians have the highest rate, with $46.1 \%$ of deaths, followed by Motorcyclists with $36.1 \%$, drivers / passengers with $17.9 \%$ and cyclists with $3.1 \%$, according to data from the Traffic Engineering Company (PAULA, 2014). A significant loss of human wealth and material happens every year. For this reason, it is necessary to take measures using technology for drastic reduction of accidents.

In the city of São Paulo, the measures taken to reduce the number of wounded and dead do not have the expected effects due to factors, mainly intrinsic to the authorities, such as lack of supervision, incentive to educational campaigns and punishment of offenders. The poor training of drivers and disrespect for traffic laws aggravate this statistic.

Around 50,000 vehicles circulate in the city of São Paulo, transporting by smartphone applications, against 38,000 taxis (PUBLICAÇÃO FOLHA, 2017). The monthly salary of the taxi driver, considering an average of the function, is $\mathrm{R} \$ 2,675.42$ (CNT, 2016), which is equivalent to U\$820.70 (the bus drive is $\mathrm{U} \$ 728.52$ ). If we consider the number of automobiles which paid yours tax, we have 2,630,236 vehicles in 2012 (PUBLICAÇÃO CONTROLAR, 2012). Then the number transporting by smartphone applications is around to $3,3 \%$.

If 50,000 vehicles are in the city of São Paulo, it equals a total of 2,600,000,000 kilometers annually. If we consider that an accident occurs every 3,200,000 kilometers per vehicle, we will have one auto accident per 0.016 year, or only one accident every 6 years. However, traffic behavior and peculiarities alter this proportion, being a reference when caring for traffic is not totally to the driver.

According to a survey of taxi drivers in metropolitan areas of Brazil, 23.4\% were involved in at least 1 traffic accident in the last 2 years. Of these, $30 \%$ admit to being the cause of distraction (CNT, 2016). If we have 38,000 taxis, would be around to 8,892 accidents and 2,668 the main cause would be distraction.

\section{AUTOMOTIVE VEHICLES IN THE NEXT 20 YEARS: A MARKET PERSPECTIVE}

Currently, many new vehicles have some level 1 automation features such as cruise control, obstruction warning, and parallel parking. Some manufactures, such as Tesla, now offer level 2 features such as automated lane guidance, accident avoidance and driver fatigue detection.

Coordinated platooning is now technically feasible but not operational because many benefits require dedicated lanes. Google level 3 test vehicles have reportedly driven hundreds of thousands of miles under restricted conditions: specially mapped routes, fair weather, and human drivers able to intervene when needed. Some manufacturers aspire to sell level 4 
automation vehicles within a few years but details are uncertain; early versions will probably be limited to "controlled" environments such as freeways.

Despite this progress, significant technical improvement is needed to achieve unrestricted level 4 operation. Since a failure could be deadly to vehicle occupants and other road users, automated driving has high performance requirements. Sensors, computers and software must be robust, redundant and resistant to abuse. Several more years of development and testing will be required before regulators and potential users gain confidence that level 4 vehicles can operate as expected under all conditions (NHTSA, 2017).

Recent announcements that autonomous vehicles have safely driven hundreds of thousands of miles and major manufactures aspire to soon sell such vehicles, and optimistic predictions of their benefits, have raised hopes that this technology will soon be widely available and solve many transportation problems. However, there are good reasons to be cautious when predicting their future role.

There is considerable uncertainty concerning autonomous vehicle benefits, costs and travel impacts. Advocates claim that they will provide large benefits that offset costs, but they will require additional equipment, services and maintenance costs that will probably total hundreds or thousands of dollars per vehicle-year, and many of their benefits are unproven.

Current automated vehicles can only self-drive under limited conditions: significant technical and economic obstacles must be overcome before most households can rely on them for daily travel. Operating a vehicle on public roads is more complex than flying an airplane due to the frequency and proximity of interactions with often-unpredictable objects including other vehicles, pedestrians, animals, buildings, trash and potholes. If they follow previous vehicle technology deployment patterns, autonomous vehicles will initially be costly and imperfect.

Today, to keep a compact car 1.0 liter in Brazil (level 0 automation) is around to $\mathrm{R} \$ 53,984.38$ (U\$16,559.63) for three years riding $15,000 \mathrm{~km}$ per year. If it was a SUV, would be $\mathrm{R} \$ 111,180.04$ (U\$34,104.31) for three years (PUBLICAÇÃO EXAME, 2016). Is it necessary to buy a car like is today model market?

During the 2020s and perhaps the 2030s, autonomous vehicles are likely to be expensive novelties with limited abilities, such as restrictions on the road conditions in which they may operate. It will probably be the 2040 s or 2050 s before middle-income families can afford to own self-driving vehicles that safely operate in all conditions, and longer before used autonomous vehicles become affordable to lower-income households.

A significant portion of motorists may resist such vehicles, just as some motorists prefer manual transmissions, resulting in mixed traffic that creates new roadway management problems. A survey conducted with 40,000 people in the city of São Paulo indicates that $85 \%$ are in favor of the marketing autonomous vehicle in the city. According to a study conducted in 2015 by ONSV (National Observatory of Road Safety) 90\% of traffic accidents occur due to the failure of the driver.

Even so, $11 \%$ of respondents argue that there would buy for the option is dangerous. The delay of the completion of works to improve on the tracks appeared as an issue. The $88.9 \%$ believe that the country and the São Paulo are not prepared to receive this modernity without first 
reforming streets and roads. The law is also a concern for who runs: More than $50 \%$ believe that it will be more difficult to define a culprit in the case of some fatal occurrence (EXAME, 2016).

Vehicle innovations tend to be implemented more slowly than other technological changes due to their high costs, slow fleet turnover and strict safety requirements. Automobiles typically cost fifty times and last ten times as long as mobile phones and personal computers, so consumers seldom purchase new vehicles just to obtain a new technology. Autonomous vehicles will probably have relatively costly equipment and service standards, similar to airplanes, which may discourage some users. Large increases in new vehicle purchase and scrappage rates would be required for most vehicles to be autonomous before 2050 .

\section{CONCLUSION}

Decree No. 45,904 of 2005 on the conservation of sidewalks and adjustments for the physically handicapped is regulated, but in practice there is no gain in the conservation of sidewalks, which negatively stimulates the use of private vehicles. The parklets favor in reducing the number of parking spaces. Even if they are punctual, the sum of them impacts on discouraging the use of the vehicle itself.

For the practice of cycling, two factors are paramount: topography and mean ambient temperature. Many cities that have a use of this modal is associated with coastal cities, which is not the case of the city object of study. The transport by autonomous vehicle tends to supply these conditions of the city and to be an alternative means to the cycling.

Mass transportation by train, subway and/ or bus will continue to be used, mainly for the population residing in dormitory cities, such as Franco da Rocha, Itapecerica da Serra, among others. The extremes of the city will stand in the same perspective. What happens is that autonomous vehicles with shared trips will have the differential to the intermodality in the means of use.

A comparison of the salary levels of bus and truck drivers equals, but human life does not. Regardless of this, a change in training and education patterns becomes fragile and the introduction of semi-autonomous or autonomous vehicles tends to reduce the level of accidents.

The systemic manufacturers is the key point for the implementation of the technology phases of the autonomous vehicles and the operationalization with the degrees of confidence in the system. Uber and Tesla lead in promoting the implementation of this technology and seek to avoid zero accidents risks.

Uber vehicles constantly increase the database for information on routes made around the world and consequently have a route learning with the support of the Waze application and the reduction of accidents with parallel roads and less traffic. This change directly affects the reduction of pollutant emissions and less time on the way.

In the city of São Paulo, the measures that are taken to reduce the number of wounded and dead, do not have the expected effects due to factors, mainly intrinsic to the authorities, such as lack 
of monitoring, equal control of all modes of motorized transportation, incentive to educational campaigns and punishment of offenders exemplarily.

An example of this is the discussion of the resumption of the increase in the speed limit on the Tietê River and Pinheiros River fringes. The traffic fatalities occurred again mainly by pedestrians on the expressway and motorcycle traffic above the speed limit between other motor vehicles. The Marginal led the number of road killings in 2015.

According to a study by Cucick et al (2015), simple actions adopted in New York City could prevent the death of approximately 245 people in the year 2014 in the São Paulo city. The methodologies exist, what is lacking is the effective employment, uniting the three pillars (3E) of traffic engineering, which are: engineering, education and enforcement.

The insertion of phases in the implantation of the autonomous vehicles will impact gradually in the reduction of accidents and in the reliability of the autonomous system, including in other modalities, like the motorcycle. A previous analysis, considering the particularities of the States of Arizona, USA, would be one an accident every 6 years.

A previous analysis, considering the particularities of the States of Arizona, USA, 8,892 accidents could be avoid each two years in the city of São Paulo.

In Tesla vehicles, with embedded Autopilot technology, even presenting a $40 \%$ reduction in accident rates, would not have significant results due to the high car value in the commercialization.

\section{REFERENCES}

ARAUJO, G.; GOMES, H. S.. DOMINGOS, R. São Paulo na Era Uber. Website: http://especiais.g1.globo.com/sao-paulo/2016/especial-uber/. Julho de 2016.

BERGEN, M.; NEWCOMER E. Uber to Suspend Autonomous Tests After Arizona Accident. https://www.bloomberg.com/news/articles/2017-03-25/uber-autonomous-vehiclegets-in-accident-in-tempe-arizona. Março, 2017.

BOUDETTE, N. E. Tesla's Self-Driving System Cleared in Deadly Crash. Webmail: https://www.nytimes.com/2017/01/19/business/tesla-model-s-autopilot-fatalcrash.html?mcubz=2\&_r=0. Janeiro, 2017.

CUCICK, F. RODRIGUES G. T., MATHEUS, L. V., MELLO FILHO, L. V. F. Estratégia para redução de mortes no trânsito da cidade de São Paulo. SIMEA, PAP169. Blucher, 2015.

DINO. 85\% dos brasileiros aprovam a venda de carros autônomos no Brasil. Website: http://exame.abril.com.br/negocios/dino/85-dos-brasileiros-aprovam-a-venda-de-carrosautonomos-no-brasil-shtml/. Dezembro de 2016.

HALL, D.; MOULTAK, M.; LUTSEY, N. Electric Vehicle Capitals of the World: demonstrating the path to electric drive. Website: 
http://www.theicct.org/sites/default/files/publications/Global-EV-Capitals_WhitePaper_06032017_vF.pdf. Março de 2017.

IBGE - Censo Demográfico 2010: Resultados gerais da amostra. Website: http://www.ibge.gov.br/home/presidencia/noticias/imprensa/ppts/00000008473104122012315 727483985.pdf. Acesso em 30 de maio de 2017.

LEI FEDERAL DA MOBILIDADE URBANA No 12.587 DE 2012 - Institui as diretrizes da Política Nacional de Mobilidade Urbana.

LEI MUNICIPAL No 15.733 DE 2013 - Introduz alterações na Lei $n^{\circ} 15.442$, de 9 de setembro de 2011, bem como torna sem efeito multas aplicadas, conforme especifica.

LEWGOY, J. Quanto custa manter um carro compacto, um sedan e um SUV. Website: http://exame.abril.com.br/seu-dinheiro/quanto-custa-manter-um-carro-compacto-um-sedan-eum-suv/. Revista Exame. Junho de 2016.

MACÁRIO, D. Em cinco anos, Linha 10 perde 8 milhões de passageiros, Diário do Grande ABC, 24 de maio de 2017.

OHNO, T. O Sistema Toyota de Produção: além da produção em larga escala. $1^{\mathrm{a}}$ edição, Porto Alegre. Editora Bookman, 1997. 137 p.

PUBLICAÇÃO COMPANHIA DE ENGENHARIA DE TRÁFEGO (CET). Relatório Anual de Acidentes de Trânsito. São Paulo: 2015.

Website: http://www.cetsp.com.br/media/490098/relatorioanualacidentestransito2015.pdf.

Acesso em: 01 de junho 2017.

PUBLICAÇÃO CONFEDERAÇÃO NACIONAL DOS TRANSPORTES (CNT).

Pesquisa Perfil dos Taxistas 2016. Website:

http://cms.cnt.org.br/Imagens\%20CNT/PDFs\%20CNT/Pesquisa\%20CNT\%20Perfil\%20dos\% 20Taxistas/Pesquisa_CNT_Perfil_dos_Taxistas_2016.pdf. Acesso em 23 de maio de 2017.

PUBLICAÇÃO DIAS ÚTEIS. http://www.dias-uteis.com/dias-uteis_feriados_2014.htm. Acesso em 24 de maio de 2017.

PUBLICAÇÃO FOLHA. Número de carros de apps supera o de táxis em SP, revela secretário de Doria. Website: http://www1.folha.uol.com.br/cotidiano/2017/02/1855880-numero-decarros-do-uber-supera-o-de-taxistas-em-sp-diz-secretario-de-doria.shtml. Fevereiro, 2017.

PUBLICAÇÃO FUTURISM. 7 Ways Tesla Is Changing Everything. Website: https://futurism.com/ready-for-edit-7-ways-tesla-is-changing-everything/.

PUBLICAÇÃO G1. Tarifas de ônibus intermunicipais serão reajustadas a partir de domingo. Website: http://g1.globo.com/sao-paulo/noticia/2013/05/tarifas-de-onibus-intermunicipaisserao-reajustadas-partir-de-domingo.html. Publicado em 29 de maio de 2013. Acesso em 24 de maio de 2017. 
PUBLICAÇÃO LOVE MONDAYS. Salário da função maquinista. Website: https://www.lovemondays.com.br/trabalhar-na-companhia-paulista-de-trens-metropolitanoscptm-1/salarios/cargo/maquinista. Acesso em 24 de maio de 2017.

PUBLICAÇÃO LOVE MONDAYS. Salário da função cobrador de ônibus na cidade de São Paulo. Website: https://www.lovemondays.com.br/salarios/cargo/salario-cobrador-de-onibus. Acesso em 24 de maio de 2017.

PUBLICAÇÃO LOVE MONDAYS. Salário da função motorista de ônibus na cidade de São Paulo. Website: https://www.lovemondays.com.br/salarios/cargo/sp/salario-motorista-deonibus-urbano/sao-paulo. Acesso em 24 de maio de 2017.

PUBLICAÇÃO METRÔ - Pesquisa de Mobilidade da Região Metropolitana de São Paulo. Principais resultados pesquisa domiciliar, dezembro de 2013.

PUBLICAÇÃO METRÔ. Inaugurados mais 2,8 km de metrô em São Paulo com três novas estações. Link: http://www.metro.sp.gov.br/noticias/06-09-2017-inaugurados-mais-28-km-demetro-em-sao-paulo-com-tres-novas-estacoes.fss. Acesso em 11 de setembro de 2017.

PUBLICAÇÃO UBER. Website: https://www.uber.com/pt-BR/our-story/. Acesso em 24 de maio de 2017.

PUBLICAÇÃO UBER. Website: http://parceirosbr.pro.br/quantos-km-por-semana-roda-umcarro-uber/. Acesso em junho de 2017.

PUBLICAÇÃO UNITED STATES DEPARTMENT OF TRANSPORTATION. Automated Vehicles. Website: https://www.nhtsa.gov/technology-innovation/automatedvehicles.

ROLNIK, R.; KLINTOWITZ D. Mobilidade na cidade de São Paulo. Website: http://www.scielo.br/scielo.php?script=sci_arttext\&pid=S0103-40142011000100007. 2011. Acesso em 01 de junho de 2017.

SOUZA, P. Vai comprar uma moto? Saiba quanto você gastará em 1 ano. Website: http://www.moto.com.br/acontece/conteudo/vai-comprar-uma-moto-saiba-quanto-vocegastara-em-1-ano-73792.html. Publicado em 17 de janeiro de 2014. Acesso em 24 de maio de 2017. 